\title{
The impacts of port infrastructure and logistics performance on economic growth: the mediating role of seaborne trade
}

\author{
Ziaul Haque Munim ${ }^{1 *}$ (D) and Hans-Joachim Schramm²,3
}

\author{
* Correspondence: \\ ziaul.h.munim@uia.no \\ ${ }^{1}$ School of Business and Law, \\ University of Agder, Kristiansand, \\ Norway \\ Full list of author information is \\ available at the end of the article
}

\begin{abstract}
Considering 91 countries with seaports, this study conducted an empirical inquiry into the broader economic contribution of seaborne trade, from a port infrastructure quality and logistics performance perspective. Investment in quality improvement of port infrastructure and its contribution to economy are often questioned by politicians, investors and general public. A structural equation model (SEM) is used to provide empirical evidence of significant economic impacts of port infrastructure quality and logistics performance. Furthermore, analysis of a multigroup SEM is performed by dividing countries into developed and developing economy groups. The results reveal that it is vital for developing countries to continuously improve the quality of port infrastructure as it contributes to better logistics performance, leading to higher seaborne trade, yielding higher economic growth. However, this association weakens as the developing countries become richer.

Keywords: international trade, economic growth, developing economies, structural equation modeling, multi group analysis, neoclassical growth theory, liner shipping connectivity
\end{abstract}

\section{Introduction}

Trade between nations has always made a significant contribution in terms of increasing wealth among the world population (Smith, 1776). Today, over $80 \%$ of all trade is seaborne (Stopford, 2009; UNCTAD, 2015). World merchandise trade volumes have grown at a modest rate of $2.3 \%$ in 2014 following the global gross domestic product (GDP) growth rate of $2.5 \%$, indicating a strong correlation between trade and GDP (UNCTAD, 2015). The history of urban development also reveals that economic advancement is especially apparent in cities with seaports (Shan et al., 2014).

Globalisation of complex industrial production processes has increased the importance of seaports in the global supply chain. Port activity is no longer limited to just cargo handling; logistics service provision in an international context has become a core part of the business (Wang and Cullinane, 2006). In this situation, the most imperative aspects of logistics performance are logistics costs and reliability of supply chains. Poor logistics facilitation takes a large toll on a country's competitive advantage, and insights in this respect were conferred by Arvis et al. (2007). In a world of just-in-

(c) The Author(s). 2018 Open Access This article is distributed under the terms of the Creative Commons Attribution 4.0 International License (http://creativecommons.org/licenses/by/4.0/), which permits unrestricted use, distribution, and reproduction in any medium, provided you give appropriate credit to the original author(s) and the source, provide a link to the Creative Commons license, and indicate if changes were made. 
time production processes, it is not only the time and cost of delivery of shipments that matters, but also its reliability and predictability. A firm's hedging costs due to poor reliability and predictability of logistics services can be significantly high in terms of higher inventory maintenance requirements (Arvis et al., 2010). The trade-off between direct freight costs and reliability varies depending on a country's commodity trade and logistics performance, which can limit the potential of developing countries to diversify from time-insensitive commodities to value-added goods (Arvis et al., 2010). Despite such significance, the impacts of port infrastructure quality and logistics performance on a country's trade and economy have been largely overlooked in the existing port economics literature.

Economic impact studies in general are essential for justifying the economic contribution of large infrastructure facility developments. "They are especially controversial when used prospectively to justify public subsidy or extraordinary planning permission" (Hall, 2004). Therefore, the aim of port impact studies is to inform the general public about the economic contribution of ports. This aim alone is not a small task, as ports facilitate socio-economic infrastructure and generate external economies that are often not visible to the general public, but consent is required whenever port facilities are established or expanded (Chang, 1978). Today, it remains undecided as to whether or not ports contribute to their surrounding national or regional economies. Some researchers (e.g. Yochum \& Agarwal, 1987, Ferrari et al., 2010, Bottasso et al., 2013, 2014, Shan et al., 2014, Chang, et al., 2014) have noted that ports stimulate the economic growth of a country or region, whereas others (e.g. Kinsey, 1981, Gripaios \& Gripaios, 1995, Jung, 2011, Deng et al., 2013) have argued that ports do not play any key role therein. The constant decline in the number of jobs at ports due to automation and the containerisation of goods has extricated the direct economic contribution of ports.

Meanwhile, many countries are planning to build up regional hub ports, following successful cases such as Singapore, Shenzhen, Hong Kong, Dubai, to name a few and expecting additional growth of their economies in forms of new service markets. This could be aided by developing transshipment facility and efficient transport network. However, the port-city relationship has changed and the urban structure of cities is no longer important for explaining the intensity and spatial distribution of maritime transport networks (Ducruet et al., 2016). Slack and Gouvernal (2015) argued that the potential for economic development through hub port development is more limited than suggested in most maritime literature. Due to structural changes in the global shipping industry, neither a port's throughput projection nor its economic contribution performs with the degree of certainty expected by the planners (Hesse, 2006). Also, the demolition of the shipping conference system in 2008 and the global financial crisis in 2009 hit the shipping industry adversely (Munim and Schramm, 2017). According to Grossmann (2008), "economic growth has shifted to newer economic sectors which require investments into different locational factors, a high quality of life and an attractive, wellfunction city-core" (p. 2063). Hence, before investing millions of dollars in building up or expanding port infrastructure, it is important to understand the extent to which ports impact national or regional economy. 
$\mathrm{Ng}$ (2013) pointed out that, with present port research concentration on day-to-day port operations (that is, port performance and competition, port management and governance, ports and supply chains), research on port-region relationships has decreased considerably since the 1990s. In order to address the significance of port infrastructure quality, logistics performance and seaborne trade, the present study investigates the following research questions (RQs): (1) Does the port infrastructure quality, logistics performance and seaborne trade of a country have any significant impact (positive or negative) on the country's economy? (2) Does the impact differ between developed and developing economies? To answer RQ1, a structural equation model (SEM) is developed to analyse how port infrastructure and logistics performance of a country affects seaborne trade, as well as the economy of a country. To answer RQ2, a multi-group SEM is formed considering two groups: developed and developing economies.

Section 2 presents a comprehensive literature review of port economic impact studies and the conceptual framework of this study. In Section 3, data and methodological issues are discussed, before the results of the empirical analysis are presented in Section 4. Section 5 discusses policy implication of the findings and concludes with future research directions.

\section{Literature and research framework}

Although many studies have justified investment into transport facilities as a stimulator of economic growth of a country or region, most of the economic impact studies concerning seaborne trade have focused on a particular seaport or a region and a clear picture of how seaborne trade benefits the world economies remains elusive. In the context of the Port of Liverpool, Kinsey (1981) argued that the impact of ports on the local economy was declining, with a decreased number of jobs directly dependent on the port at that time. British ports were no longer major employers and the industrial inter-related complexities no longer existed, further reducing the impact of ports on the local economy (Gripaios and Gripaios, 1995). Two relatively recent studies, one in the context of South Korea (Jung, 2011) and another in the context of China (Deng et al., 2013), have also argued that ports are having declining effects on economy. In particular, Jung (2011) identified that from 1990 to 2008, South Korea experienced 87.5\% decrease in the direct port employment creation effect per billion Korean won. Despite no significant impact of seaborne trade on economic growth, Deng et al. (2013) revealed significant positive association between regional economy and value added activity at Chinese ports. The reasons for such association could be that Deng et al. (2013) included total volume of imports and exports in the value-added activity construct, which is actually part of the port demand (i.e. seaborne trade) construct.

The benefits of investing in transport infrastructure are not limited to travel-time saving (Banister and Berechman, 2001). Lakshmanan (2011) showed that improved freight services lead to growing trade, followed by improved labor supply and technical diffusion. Some port impact studies in the context of the USA (Yochum and Agarwal, 1987), European countries (Bottasso et al., 2013; Bottasso et al., 2014; Ferrari et al., 2010), China (Shan et al., 2014) and South Africa (Chang et al., 2014) have observed significant impact of port activity on regional/national economies. Yochum and Agarwal (1987) concluded that some firms located in Hampton, USA, would 
experience a severe economic penalty due to a shortage of ports. Bottasso et al. (2013) analysed the impact of ports on local employment, using a sample of 560 regions located in 10 West European countries. They found that every million tons of net port throughput would create about 400-600 jobs in the region. Furthermore, Bottasso et al. (2014) found that every $10 \%$ increase in port throughput can generate a 6-20\% increase in the GDP of the regions and can have a spillover effect on neighbouring regions in the range of $5-18 \%$. In the context of China, Shan et al. (2014) found that $1 \%$ increase in port cargo throughput can increase GDP per capita growth by $7.6 \%$, and the port throughput of a country has a positive impact on neighbouring economies. Similarly, Chang et al. (2014) revealed that the South African economy could suffer a $17 \%$ loss due to a single unit shortage in port activity.

A summary of selected port impact studies since the 1980s is presented in Appendix A. Most of these studies employed either input-output analysis or regression analysis, and focused only on a particular port of a country or region. What is lacking is that, none of those studies considered port infrastructure quality and logistics performance but focused solely on port throughputs. Therefore, the present study examines the wider economic benefits of port infrastructure quality, logistics performance and seaborne trade through analysis of national-level data of 91 countries.

\section{Conceptual framework}

In this paper, the approach used to estimate economic impact of port infrastructure quality is based on the neo-classical economic perspective of transport infrastructures proposed by Lakshmanan (2011). We have assumed that investments into port infrastructure are exogenous, which improve the quality of port infrastructure (QPI). Better QPI (such as modern technologies and equipment) would help improve the logistics performance (LP) of a country (that is, greater reliability, less damage, ability to track and trace shipments, timeliness of delivery etc.). Improved QPI and LP would increase the local and global accessibility of a country, including opportunities to expand markets worldwide. The realisation of those opportunities can be expressed in the form of a country's total international trade (herein, seaborne trade). Gains from trade can be characterised by improved labor supply, expanded production, diffusion of innovation, competitive pressures, economic restructuring, etc., leading to total factor productivity and GDP growth (Lakshmanan, 2011). To sum up, Fig. 1 presents the conceptual framework of this study.

First, we examine the effects of QPI on LP, seaborne trade (ST) and national economy (NE) based on the conceptual framework in Fig. 1. We then look at the effects of LP on ST and NE, and then the effect of ST on NE is examined. Finally, the indirect (or mediated) effects of QPI on NE via LP, QPI on NE via ST, and QPI on NE via LP and ST are investigated.

\section{Hypothesis development}

Competition among countries is an everlasting phenomenon. In the game of becoming better than each other and attaining competitive advantage, access to 


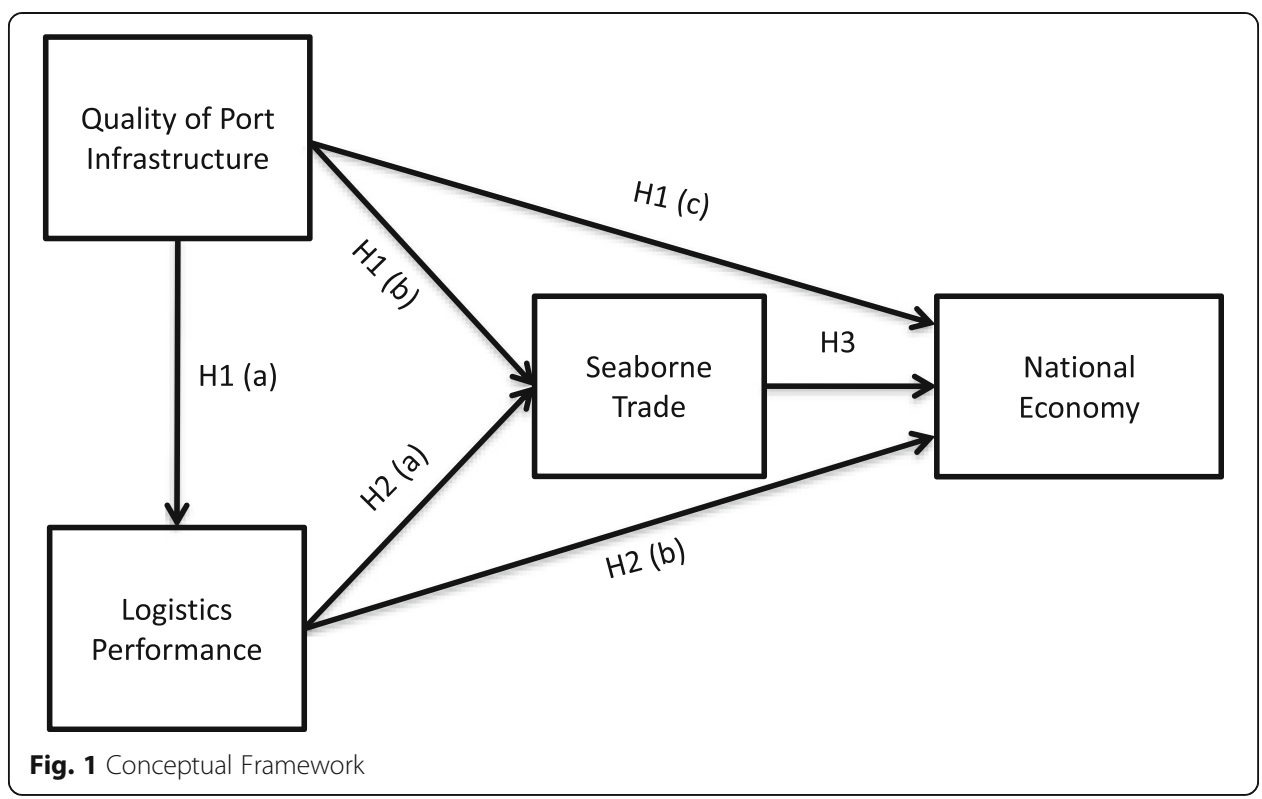

resources and new markets; governments around the world are making intensive investments into different developmental projects. Such projects also include the development of new ports or expansion of existing ones. Nowadays, the role of ports is not limited to cargo handling but also includes the provision of better logistics services to meet the growing demands of global supply chains. "Logistics performance refers to cost, time, and complexity in accomplishing import and export activities" (Hausman et al., 2013, p. 236). Advanced technologies facilitate better logistics performance through reengineering transport routes, scale, modes or frequencies (Helling and Poister, 2000). Along with technology and service quality, Song and Panayides (2008) highlighted the importance of value-added activities at ports by means of diverse logistics services to attain competitive advantage. The ability of a country to offer diverse logistics services is partly driven by the quality of physical infrastructures such as road, rail, and ports (Subramanian and Arnold, 2001). Physical infrastructure is an important determinant of transport cost (i.e. a component of logistics performance), particularly for landlocked countries (Limao and Venables, 2001). Also, innovations in containerisation and intermodal transport have been part of major changes in global logistics over the past 20 years (Memedovic et al., 2008). Thus, it can be hypothesised that:

\section{H1 (a): The quality of port infrastructure has a positive effect on logistics} performance.

In the same vein, investments in physical infrastructure creates a better business environment and improves transport efficiency, which facilitates export growth (Portugal-Perez and Wilson, 2012). Yeo et al. (2008) found that quality of port service, logistics costs, regional connectivity, hinterland condition and port accessibility, contributes significantly to a port's competitiveness. Similarly, Notteboom et al. (1997) stated that a combination of infrastructure quality, hinterland accessibility 
and productivity plays a vital role in strengthening a port's competitive position. Gordon et al. (2005) added that a combination of port facilities, including sufficient investment, supportive government policies, excellence in operation and information technology, can help a port attain sustainable competitiveness, which will produce higher seaborne trade compared to the less competitive ports. Thus, it can be hypothesised that:

H1 (b): The quality of port infrastructure has a positive effect on seaborne trade.

Lakshmanan (2011) proposed that investment into transport facilities improves logistics ability and reduces freight costs. Wilmsmeier and Hoffmann (2008) estimated the role of liner shipping connectivity (LSC) and port infrastructure in determining freight rates in the Caribbean. They found that a one-standard-deviation increase in LSC implies an expected reduction of USD 287 in freight rate, and that a one-standarddeviation increase in port infrastructure for an importing country implies an expected reduction of USD 225 in freight rate. Furthermore, Sánchez et al. (2003) found that freight costs are lower in efficient ports after controlling for distance, liner service availability, type of product and insurance costs. Also, an increase in port efficiency from the 25th to the 75th percentile is expected to reduce shipping costs by $12 \%$ (Clark et al., 2004). Quality of infrastructure and transport costs are important for export-led economic growth (Limao and Venables, 2001). Thus, it can be derived that efficient ports have better quality infrastructure and logistics performance than inefficient ones. Additionally, an efficient port system with enhanced logistic abilities is a key determinant of foreign direct investment into a country (Panayides et al., 2015). On the other hand, inefficient ports reduce national and international trade and affect economic growth adversely (Clark et al., 2004). Also, the role of ports in the internationalisation process of business firms was highlighted by Ellis (2011). Thus, the following hypotheses could be derived from the above arguments:

$H 1$ (c): The quality of port infrastructure has a positive effect on national economy.

$H 1$ (d): The quality of port infrastructure has a positive effect on national economy mediated through logistics performance.

H1 (e): The quality of port infrastructure has a positive effect on national economy mediated through seaborne trade.

H1 (f): The quality of port infrastructure has a positive effect on national economy mediated through logistics performance and seaborne trade.

A country's logistics performance plays a vital role in facilitating transportation of goods to the international market. "Inefficient logistics services impede trade by imposing an extra cost in terms of time as well as money" (Korinek and Sourdin, 2011, p. 2). Limao and Venables (2001) found a significant negative association between transport cost and international trade. Long customs clearance time adversely affects firms' total factor productivity (Subramanian et al., 2005). Meanwhile, a better business environment comprising quality logistics services is associated with better export performance 
(Portugal-Perez and Wilson, 2012). Also, better accessibility of freight increases logistics employment (van den Heuvel et al., 2014). Overall, firms in countries with better logistics performance have higher probability of exporting to international markets and attracting foreign direct investments (Hausman et al., 2013). Thus, logistics development has a positive impact on regional economic growth (Chu, 2012; Lean et al., 2014; Li et al., 2017; Lun et al., 2016). Coto-Millán et al. (2013) found that a 1\% increase in logistic performance index can increase the world economic growth by between 1.13.4\%. Therefore, we propose the following hypotheses:

H2 (a): Logistics performance has a positive effect on seaborne trade.

H2 (b): Logistics performance has a positive effect on national economy.

H2 (c): Logistics performance has a positive effect on national economy mediated through seaborne trade.

Ports are the hub and node of networks for all kinds of waterborne transport and link countries with rest of the world; thus, they promote transportation and distribution in the cheapest way. Ports are more than just an infrastructure that facilitates international trade; they also determine freight transport costs and help companies access international markets (Clark et al., 2004). Although the most visible economic contribution of ports was employment in the port, this has declined dramatically since the inception of containerisation, although ports still contribute significantly to the overall economy in rather less visible forms. In this present era of globalisation, products are usually produced far away from consumer markets, and raw materials for a single product are often sourced from several different countries. Also, vertical specialisation has increased dramatically over the last two decades; that is, different parts of the production function of a product are performed in different countries (Hummels et al., 2001). This would have not been possible without the support of efficient maritime transport. Overall, the contribution of maritime transport nowadays is invisible to ordinary people, but spread over different industries and institutions to such an extent that it can hardly be measured accurately. Helling (1997) outlined how a dollar's worth of water transportation is spread over 10 different but interrelated business categories. Sleeper (2012) found that GDP is positively proportionate to the number of worldwide recognised ports in a country. In an analysis of 120 port regions from 13 European countries, Bottasso et al. (2014) revealed that ports increase the GDP of regions in which they are located, and also influence neighbouring regions' GDP positively. Park and Seo's (2016) investigation of South Korean port regions found that the container throughput of a port has a positive effect on regional economic growth. Thus, we hypothesise that:

H3: Seaborne trade has a positive effect on national economy.

\section{Data and methodology}

Data regarding all observed variables of latent constructs of this empirical analysis are collected on an annual basis per country from the World Bank database 
(data.worldbank.org). To capture the impact of port infrastructure quality and remove potential bias from small island economies with negligible economic activity on a global scale, we have selected countries that have seaports with yearly container traffic of 200,000 twenty equivalent units (TEUs). In total, 91 countries were considered for analysis (see Appendix C). Most of the previous impact studies discussed in Section 2 used a defined set of observed variables on empirical levels. However, when it comes to multi-facet, hardly direct measurable issues like logistics performance and seaborne trade, the essence to develop latent constructs using multiple observed indicators becomes relevant. Therefore, we designed a set of latent variables consisting of multiple observed indicators. This served as the motivation to select structural equation modelling (SEM) as the appropriate method of analysis. According to Kline (2005), a sample size for complex SEM should be more than 100. Accordingly, data have been pooled from three years (namely 2010, 2012 and 2014), generating 228 observations, except for observations with missing values. Table 1 lists all the latent constructs with observed indicators along with their codes.

The quality of port infrastructure (QPI) construct is formed with one observed variable, named QPI, which covers business executives' perception of their country's port facilities. Data are on a Likert scale from 1 to 7 , where 1 represents the port infrastructure considered extremely underdeveloped and 7 represents efficient by international standards (see http://data.worldbank.org/indicator/IQ.WEF.PORT.XQ for details).

The logistics performance construct consists of six indicators as listed in Table 1. Lun et al. (2016) used the same set of LP data as a proxy for trade facilitation. The set of LP indicators is based on empirical survey data collected by the World Bank on a regular basis. The LP Index measures logistics performance on the country level through asking operators on the ground (global freight forwarders and express carriers) to provide feedback on the logistics "friendliness" of the countries in which they operate (see http://lpi.worldbank.org/ for further details).

Seaborne trade can be expressed by container or cargo throughput, as used by Deng et al. (2013) and Shan et al. (2014). However, throughput alone cannot totally represent the value and intensity of seaborne trade of a country. Therefore, a latent construct

Table 1 List of observed and latent variables

\begin{tabular}{lll}
\hline Latent Construct & Observed Indicators & Abbreviation \\
\hline $\begin{array}{l}\text { Quality of port } \\
\text { infrastructure (QPI) }\end{array}$ & Quality of port infrastructure & QPI \\
Logistics performance (LP) & Ability to track and trace consignments & LPIAT \\
& Competence and quality of logistics services & LPICQ \\
& Ease of arranging competitively priced shipments & LPIEA \\
& Efficiency of customs clearance process & LPIEC \\
& Frequency with which shipments reach & LPIFS \\
& consignee within scheduled or expected time & \\
Seaborne trade (ST) & Quality of trade and transport-related infrastructure & LPIQT \\
& Container port traffic ('O00 TEUs) & CT \\
National economy (NE) & Liner shipping connectivity index & LSC \\
\hline
\end{tabular}


with country-level container throughput in TEUs and liner shipping connectivity index is formed. The LSC index represents the connectivity of countries with each other in the form of a global liner shipping network. The LSC index is based on five maritime transport components (i.e. number of ships handled, their container-carrying capacity, maximum vessel size, number of services, and number of companies that deploy container ships in a country's ports; see http://data.worldbank.org/indicator/IS.SHP.GCNW.XQ for details). A correlation matrix of all the latent constructs is depicted in Appendix B.

The economics literature usually uses total GDP or GDP per capita to measure economy at a country level. Therefore, we used per capita GDP, after controlling for purchasing power parity, to form the national economy construct using a single indicator. As data used for empirical analysis involve large numbers, it is log transformed, and their descriptive statistics are presented in Table 2.

\section{Empirical analysis and findings}

This section presents empirical analysis and findings with respect to the research questions stated in Section 1. First, normality of latent variables has been checked through the Shapiro-Wilk test and Q-Q plots of residuals of variables. As none of the variables are normally distributed, the Satorra-Bentler rescaling method has been employed for SEM estimation, as suggested by Rosseel (2012). Validity and reliability statistics of the conceptual model (proposed in Section 2) are then performed. After validation and reliability check, the final SEM and multi-group SEM are presented.

\section{Validity and reliability}

Standardised factor loadings, squared multiple correlations (SMC) and model fit indices are considered to be the key statistical criteria for an acceptable measurement model (Koufteros, 1999). Table 3 summarises the statistical criteria of the measurement model. $\mathrm{R}^{2}$ represents the squared multiple correlations and all the values are above the recommended level of 0.50 (Bollen, 1989; Lu et al., 2007). In addition, all standardised factor loadings are above the recommended level of 0.70 and statistically significant. Furthermore, a good measurement model fit is

Table 2 Descriptive statistics of variables

\begin{tabular}{lllllllll}
\hline Variables & $N$ & Mean & S.D. & Min & Max & Skewness & Kurtosis & Shapiro-Wilk test \\
\hline QPI & 228 & 1.51 & 0.23 & 0.88 & 1.92 & -0.39 & -0.36 & $0.98^{* *}$ \\
LPIAT & 228 & 1.15 & 0.18 & 0.71 & 1.44 & -0.18 & -0.82 & $0.97^{* * *}$ \\
LPICQ & 228 & 1.11 & 0.19 & 0.74 & 1.44 & 0.07 & -1.11 & $0.96^{* * *}$ \\
LPIEA & 228 & 1.11 & 0.14 & 0.73 & 1.43 & -0.22 & -0.50 & $0.99^{*}$ \\
LPIEC & 228 & 1.05 & 0.21 & 0.62 & 1.44 & 0.04 & -1.11 & $0.96^{* * *}$ \\
LPIFS & 228 & 1.27 & 0.15 & 0.88 & 1.51 & -0.31 & -0.90 & $0.96^{* * *}$ \\
LPIQT & 228 & 1.09 & 0.22 & 0.56 & 1.47 & 0.04 & -1.06 & $0.96^{* * *}$ \\
CT & 228 & 14.63 & 1.50 & 11.52 & 19.02 & 0.32 & -0.56 & $0.97^{* * *}$ \\
LSC & 228 & 3.28 & 0.88 & 1.25 & 5.11 & -0.28 & -0.66 & $0.98^{* *}$ \\
PGDP & 228 & 9.7 & 1.00 & 6.80 & 11.85 & -0.54 & -0.38 & $0.96^{* * *}$ \\
\hline
\end{tabular}

$N$ number of observations, S.D. standard deviation ${ }^{*} p<0.05,{ }^{* *} p<0.01,{ }^{* * *} p<0.001$ 
Table 3 Summary Results of Measurement Model

\begin{tabular}{lllllll}
\hline $\begin{array}{l}\text { Latent } \\
\text { Construct }\end{array}$ & $\begin{array}{l}\text { Observed } \\
\text { Indicators }\end{array}$ & $\begin{array}{l}\text { Unstandardized factor } \\
\text { loadings }\end{array}$ & $\begin{array}{l}\text { Standardized factor } \\
\text { loadings }\end{array}$ & $\begin{array}{l}\text { Standard } \\
\text { error }\end{array}$ & $\begin{array}{l}\text { Z- } \\
\text { value }\end{array}$ & $\begin{array}{l}R^{2} \text { (item } \\
\text { reliability) }\end{array}$ \\
\hline QPI & QPI & 0.23 & $1.00^{* * *}$ & 0.01 & 24.61 & 1.00 \\
LP & LPIAT & 0.17 & $0.93^{* * *}$ & 0.01 & 24.62 & 0.86 \\
& LPICQ & 0.18 & $0.97^{* * *}$ & 0.01 & 29.75 & 0.94 \\
& LPIEA & 0.12 & $0.85^{* * *}$ & 0.01 & 19.40 & 0.73 \\
& LPIEC & 0.20 & $0.95^{* * *}$ & 0.01 & 27.93 & 0.90 \\
& LPIFS & 0.13 & $0.87^{* * *}$ & 0.01 & 22.55 & 0.76 \\
& LPIQT & 0.22 & $0.97^{* * *}$ & 0.01 & 29.42 & 0.95 \\
& CT & 1.46 & $0.98^{* * *}$ & 0.07 & 20.28 & 0.95 \\
& LSC & 0.78 & $0.88^{* * *}$ & 0.04 & 19.24 & 0.77 \\
& PGE & 0.99 & $1.00^{* * *}$ & 0.04 & 23.16 & 1.00 \\
\hline
\end{tabular}

Model-fit: $\mathbf{X}^{2}(31)=81.93, \mathrm{CFI}=0.98, \mathrm{TLI}=0.97, \mathrm{RMSEA}=0.09, \mathrm{SRMR}=0.02$

${ }^{*} p<0.05,{ }^{* *} p<0.01,{ }^{* * *} p<0.001$

indicated as the Tucker Lewis Index (TLI) and Comparative Fit Index (CFI) are both well above the recommended level of 0.90 .

In addition to the model fit indices and SMC, we also checked the reliability of the latent constructs. Reliability is referred to by the value of Cronbach's Alpha. The Cronbach's Alpha (Cronbach, 1951) values of the constructs LP and ST are 0.97 and 0.86, respectively; both values exceed the required level of 0.70 as suggested by Nunnally (1978). This also confirms internal consistency of the latent constructs (Garver and Mentzer, 1999).

To test for convergent validity, we examined the statistical significance of the factor loadings through their z-values (also stated as t-values, Dunn et al., 1994). As a rule of thumb, acceptable estimates should have z-values higher than 2 or less than -2 (Hair et al., 2006; Koufteros, 1999). As depicted in Table 3, all z-values of indicators are higher than 2 , which means that all indicators measure their respective latent construct, and confirm the uni-dimensionality and convergent validity of each construct (Anderson and Gerbing, 1988). As all the $\mathrm{R}^{2}$ values are above 0.50 , item reliability is also confirmed. To assess discriminant validity, a series of pairwise confirmatory factor analyses (CFA) were conducted. In this process, a non-constrained CFA of one pair of constructs was compared with a constrained CFA at a time to avoid the influence of construct pairs with significant values over non-significant ones (Anderson and Gerbing, 1988). All the chi-square difference test results were statistically significant $(p<0.001)$, providing evidence of the discriminant validity of the constructs.

\section{Structural equation model}

As the measurement model and reliability tests have confirmed validity and reliability, the structural equation model is proceeded. The parameter estimations, model fit indices, and the results of hypotheses proposed in Section 2.2 are presented and discussed.

The SEM, including estimated standardised factor loadings and regression coefficients, is presented Fig. 2, along with their respective paths. All 10 factors loadings are above the recommended level of 0.70 and are statistically significant. The structural model has a good fit with chi-square $\left(\mathrm{X}^{2}\right)$ of 73.78 , and the ratio of $\mathrm{X}^{2}$ and degrees of freedom (that is, $73.78 / 30=2.46<3$ ) is within the required level recommended by 


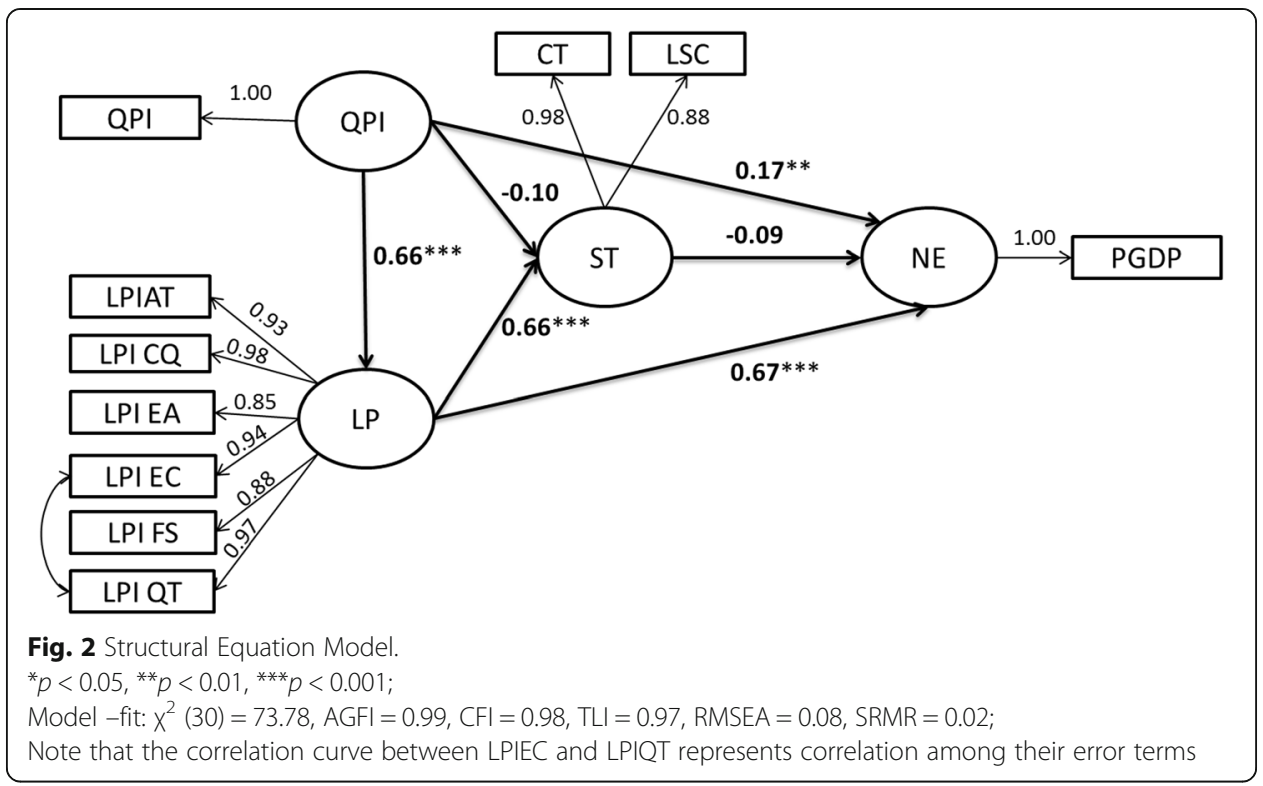

Bollen and Long (1993). The Adjusted Goodness of Fit Index (AGFI) is 0.99, meaning the estimated model predicted $99 \%$ of the variances and co-variances in the observed data. Moreover, other fit index measures, such as CFI (0.98) and TLI (0.97), are well above the minimum requirements. Finally, the root mean-square error of approximation $($ RMSEA $=0.08)$, as well as the standardised root mean square residual $(S R M R=$ 0.02), confirmed a good fit of the SEM.

After confirming the fitness of the proposed SEM, we estimated the hypothesised relationships between the latent constructs. The estimates of the hypothesised relationships and their significance are presented in Table 4. Before establishing mediation relationship among the variables (that is in H1d, H1e, H1f and H2c), the direct association between independent and dependent variable as well as its association with the mediation variable was confirmed (see Additional file 1.

Based on the statistical significance of the regression coefficients depicted in Table 4, this study finds support for H1 (a), H1 (c), H1 (d), H2 (a) and H2 (b). The other hypotheses are not supported. Thus, quality of port infrastructure has a positive effect on

Table 4 Results of Structural Equation Modelling

\begin{tabular}{llllll}
\hline Hypotheses & Regression paths & Std. Estimates & S.E. & C.R. & Remarks \\
\hline $\mathrm{H} 1($ a) & $\mathrm{QPI} \rightarrow \mathrm{LP}$ & $0.66^{* * *}$ & 0.04 & 12.93 & Supported \\
$\mathrm{H} 1(\mathrm{~b})$ & $\mathrm{QPI} \rightarrow \mathrm{ST}$ & -0.10 & 0.40 & -1.60 & Not supported \\
$\mathrm{H} 1(\mathrm{c})$ & $\mathrm{QPI} \rightarrow \mathrm{NE}$ & $0.17^{* *}$ & 0.25 & 2.80 & Supported \\
$\mathrm{H} 1(\mathrm{~d})$ & $\mathrm{QPI} \rightarrow \mathrm{LP} \rightarrow \mathrm{NE}$ & $0.45^{* * *}$ & 0.20 & 9.31 & Supported \\
$\mathrm{H} 1(\mathrm{e})$ & $\mathrm{QPI} \rightarrow \mathrm{ST} \rightarrow \mathrm{NE}$ & 0.01 & 0.04 & 1.06 & Not supported \\
$\mathrm{H} 1(\mathrm{f})$ & $\mathrm{QPI} \rightarrow \mathrm{LP} \rightarrow \mathrm{ST} \rightarrow \mathrm{NE}$ & -0.04 & 0.10 & -1.83 & Not supported \\
$\mathrm{H} 2($ a) & $\mathrm{LP} \rightarrow \mathrm{ST}$ & $0.66^{* *}$ & 0.65 & 8.99 & Supported \\
$\mathrm{H} 2(\mathrm{~b})$ & $\mathrm{LP} \rightarrow \mathrm{NE}$ & $0.67^{* *}$ & 0.38 & 10.53 & Supported \\
$\mathrm{H} 2(\mathrm{c})$ & $\mathrm{LP} \rightarrow \mathrm{ST} \rightarrow \mathrm{NE}$ & -0.06 & 0.21 & -1.81 & Not supported \\
$\mathrm{H} 3$ & $\mathrm{ST} \rightarrow \mathrm{NE}$ & -0.09 & 0.03 & -1.95 & Not supported \\
\hline
\end{tabular}

Std. Estimate standardized estimates, S.E. standard error, C.R. critical ratio ${ }^{*} p<0.05,{ }^{* *} p<0.01,{ }^{* * *} p<0.001$ 
logistics performance and national economy. Logistics performance has a positive effect on seaborne trade and national economy. The effects of quality of port infrastructure and logistics performance on national economy were found to be significant. While the mediation effect of port infrastructure quality on national economy via logistics performance is found significant, the mediation effect via seaborne trade was found to be insignificant. Also, the mediation effect of logistics performance on national economy through seaborne trade was found to be insignificant. To further investigate whether the findings are similar for both developed and developing economies, a multi-group SEM is formed and estimated in the next section.

\section{Multi group analysis}

A useful extension of the SEM is multi-group analysis, which allows for the investigation of model fit of a specific model for different groups. Some studies have compared different groups in terms of inequality. Due to immense inequality of regional economic development, Chu (2012) and Li et al. (2017) compared the impact of logistics development on regional economic growth of China for coastal provinces and inland provinces. Similarly, port infrastructure quality, logistics performance and seaborne trade may have varying impact on different economies of the world. Therefore, the sample of 91 countries has been divided into two groups: developed and developing economies. The World Bank classification of country economics was used to group the countries. Based on World Bank classification, countries with gross national income (GNI) per capita higher than 12,475 USD were considered as developed economies $(N=103)$, while others with GNI per capita below 12,475 USD were considered as developing economies $(N=125)$.

The goal of multi-group analysis is to compare the means or regression coefficients across groups, and this requires that measurement of variables used are equivalent across groups. This is usually done by comparing models with equality constraints on different parameters across groups with the configural model (that is, a reasonable multi-group SEM without any invariance constraints). A comparison between this configural model and other models with different equality constraints is depicted in Table 5.

As the difference between the configural and equal factor loadings model is not statistically significant, metric invariance is established. Therefore, comparison of regression coefficients between the developed and developing economy group can be conducted. Table 6 presents the regression coefficients of the multi-group SEM for developed and developing economies.

The multi-group SEM demonstrates good model fit as the ratio of $\mathrm{X}^{2}$ and degrees of freedom is below three (that is, $132.33 / 68=1.95$ ). All other fit indices, such as CFI, TLI, AGFI, RMSEA and SRMR, are also within the recommended

Table $\mathbf{5}$ Comparison of model fit statistics for invariance test

\begin{tabular}{llllll}
\hline Model(s) & $\Delta \mathrm{x}^{2}$ & $\Delta \mathrm{df}$ & $\Delta$ CFI & $\Delta$ RMSEA & $P$ value \\
\hline MG: Configural $\left(\mathrm{X}^{2}=182.38\right)$ & - & - & - & - & - \\
MG Vs. MG2: Equal loadings & 10.21 & 6 & 0.003 & 0.002 & 0.12 \\
MG Vs. MG3: Equal intercepts & 30.07 & 7 & 0.014 & 0.008 & $<0.05$ \\
\hline
\end{tabular}

$M G$ multi-group model, $\triangle d f$ change in degrees of freedom, $\triangle C F I$ change in Comparative Fit Index, $\triangle R M S E A$ change in Root Mean-Square Error of Approximation 
Table 6 Comparison of regression coefficients

\begin{tabular}{|c|c|c|c|c|}
\hline \multirow[b]{2}{*}{ Regression paths } & \multicolumn{2}{|c|}{ Developed Economies } & \multicolumn{2}{|c|}{ Developing Economies } \\
\hline & Std. Estimates & C.R. & Std. Estimates & $C . R$ \\
\hline $\mathrm{QPI} \rightarrow \mathrm{LP}$ & $0.52^{* * *}$ & 6.99 & $0.31^{* * *}$ & 4.08 \\
\hline $\mathrm{QPI} \rightarrow \mathrm{ST}$ & 0.03 & 0.34 & 0.09 & 1.43 \\
\hline $\mathrm{QPI} \rightarrow \mathrm{NE}$ & $0.29^{*}$ & 2.34 & -0.10 & -1.14 \\
\hline $\mathrm{QPI} \rightarrow \mathrm{LP} \rightarrow \mathrm{NE}$ & 0.14 & 1.86 & 0.04 & 1.05 \\
\hline $\mathrm{QPI} \rightarrow \mathrm{ST} \rightarrow \mathrm{NE}$ & -0.001 & -0.28 & 0.03 & 1.24 \\
\hline $\mathrm{QPI} \rightarrow \mathrm{LP} \rightarrow \mathrm{ST} \rightarrow \mathrm{NE}$ & -0.01 & -0.42 & $0.09^{*}$ & 2.35 \\
\hline $\mathrm{LP} \rightarrow \mathrm{ST}$ & $0.51^{* * *}$ & 4.46 & $0.76^{* * *}$ & 8.15 \\
\hline $\mathrm{LP} \rightarrow \mathrm{NE}$ & 0.28 & 1.89 & 0.14 & 1.20 \\
\hline $\mathrm{LP} \rightarrow \mathrm{ST} \rightarrow \mathrm{NE}$ & -0.02 & -0.42 & $0.28^{* *}$ & 2.73 \\
\hline $\mathrm{ST} \rightarrow \mathrm{NE}$ & -0.07 & -0.58 & $0.37^{* *}$ & 2.70 \\
\hline
\end{tabular}

Std. Estimate standardized estimates, C.R. critical ratio

Model -fit: $\mathbf{X}^{2}(68)=132.33, \mathrm{AGFI}=0.99, \mathrm{CFI}=0.97, \mathrm{TLI}=0.96, \mathrm{RMSEA}=0.09, \mathrm{SRMR}=0.05$

${ }^{*} p<0.05,{ }^{* *} p<0.01,{ }^{* * *} p<0.001$

level. The findings of the multi-group analysis are remarkable. Quality of port infrastructure has a positive effect on logistics performance in both developed and developed economies, but the quality of port infrastructure affects national economy only in developed economies. However, the mediated effect of port infrastructure quality on national economy through logistics performance and seaborne trade is significant in developing economies. Furthermore, logistics performance has a positive effect on national economy for both developed and developing economies.

\section{Discussion and conclusion}

This study examined associations among quality of port infrastructure, logistics performance and seaborne trade, and their effects on national economy. Overall, the results show that improvement in quality of port infrastructure and logistics performance would bring the greatest benefits to the economy of a country. The study revealed that the quality of port infrastructure has a significant positive effect on national economy, which is similar to Ferrari et al. (2010), Bottasso et al. (2014), Park and Seo (2016) and others, who observed positive effects of seaports on the economy. Our findings are also similar to those of Deng et al. (2013) as we found no association between seaborne trade (i.e. port demand) and national economy.

However, quality of port infrastructure significantly affects the logistics performance of a country. Similar to Hausman et al. (2013), we also found that logistics performance affects the seaborne trade of a country. Most of the studies that foresaw diminishing impact of seaports on economy emphasised employment generation within ports (Gripaios and Gripaios, 1995; Kinsey, 1981; Jung, 2011). However, Helling and Poister (2000) mentioned that ports that retain direct portrelated employment lose their ability to compete for cargo, which leads to a lower number of jobs in the long-run. Economic development is associated much more with the long-term capability of a port to attract more customers while creating and retaining employment and income (Helling, 1997). A dollar's worth of maritime transportation requires inputs from at least 10 interrelated transport and 
logistics industries (Helling and Poister, 2000). Therefore, if the quality of port infrastructure is not improved continuously, it may have a substantial adverse impact on the economy of a country.

Further, the extension to multi-group analysis reveals important findings, especially for developing economies. Seaborne trade partially mediates the impact of port infrastructure quality and logistics performance on economic growth in developing countries. PortugalPerez and Wilson (2012) found that the impact of transport efficiency (a component of logistics performance) on export performance decreases as the economy becomes richer. Similarly, the present study found that logistics performance has a higher impact on seaborne trade in developing economies than developed ones. For developing economies, we also found that quality of port infrastructure positively affects logistics performance; better logistics performance yields higher seaborne trade, and higher seaborne trade yields economic growth. Therefore, policy makers in developing countries should consider investing in quality improvement of port infrastructure and logistics performance, compared to larger investments in the building of new physical infrastructures (Portugal-Perez and Wilson, 2012). Policy makers in developed countries should also consider maintaining high-quality port infrastructure, as this has a positive effect on logistics performance and national economy. Korinek and Sourdin (2011) stated that "as developed nations shift from traditional manufacturing and agriculture and are increasingly engaging in international vertical specialisation, the need for efficient logistics services becomes ever more important" (p. 2). As of 1990, although smaller countries of the OECD database had a higher share of vertical specialisation than the overall OECD share; the overall share increased by about $30 \%$ between 1970 and 1990 (Hummels et al., 2001).

However, the reasons for the lack of any significant association between seaborne trade and national economy for developed economies could be: (1) the growth rates of GDP per capita compared to seaborne trade of the developed countries is lower than that of developing countries in general, and (2) developed countries are service-based economies and the role of seaborne trade is often one-way (imports), while developing countries tend to be more industry-based and trade plays a two-way role (both imports and exports). Meanwhile, attempts to stimulate economic growth by major developed economies - such as Brexit by the United Kingdom, and the United States President Donald Trump's approach towards bringing back major industrial production facilities to the USA - could, if followed by other developed nations, change the current association between seaborne trade and economy in the future.

Overall, the findings of the study are consistent with the existing transport economics literature, which underlines the fundamental contributions of port infrastructure quality and logistics performance to the economic growth of a country. However, associations among the quality of port infrastructure, logistics performance and seaborne trade, and their effects on yearly growth of country economy, should be further examined using latent growth models. It would be interesting for future studies to investigate the interaction effect between port size and economy classification. Investigation of the comparative economic impact of hub and gateway ports could also be considered. Studies should also examine the impact that quality of port infrastructure and logistics performance has on the growth of neighbouring landlocked countries' economy. Finally, economic contribution of value added activities at ports (e.g. through development of logistics parks) may also be investigated in future research (Munim and Saeed, 2016). 


\section{Appendix A}

Table $\mathbf{7}$ Key studies from the last three decades

\begin{tabular}{lll}
\hline Author & Method (s) & Data \\
\hline Kinsey & Multiplier & Employment, wage and salary, \\
(1981) & Approach & turnover, throughput etc. \\
& \\
& \\
$\begin{array}{l}\text { Yochum } \\
\text { and }\end{array}$ & Input-output & Employment, tax, 39 industry \\
Agarwal & Analysis & \\
(1987) & &
\end{tabular}

\begin{tabular}{ll} 
Finding(s) & Country \\
\hline Impact of Liverpool port on & Liverpool, \\
local economy was declining. & UK \\
Firms supplying to port was & \\
only dependent for a very & \\
small portion of their t & \\
otal revenue. &
\end{tabular}

At least some firms would

Port of suffer severe economic penalty in absence of port

Hampton, facilities. 3999 primary

jobs were created from industries located in Hampton.

$\begin{array}{lll}\begin{array}{l}\text { Gripaios } \\ \text { and } \\ \text { Gripaios } \\ \text { (1995) }\end{array} & \begin{array}{l}\text { Input-output } \\ \text { Analysis }\end{array} & \begin{array}{l}\text { GDP, direct and indirect } \\ \text { employment }\end{array} \\ \text { Ferrari } & \text { Regression, } & \text { Employment, T } \\ \text { et al. } & \text { Tobit Model, } & \text { hroughput, } \\ \text { (2010) } & \text { LS Estimates } & \text { Transport etc. } \\ \text { Jung } & \text { Descriptive } & \text { Port throughput, } \\ \text { (2011) } & & \text { economic indicators }\end{array}$

Ports are not big employers of labour and are no longer Plymouth, the inter-related industrial complexes that ports once were.

Positive impact observed. The impact of port depends on the sector being considered.

No strong effect on production and value added inducement USA coefficient over 1990-2008.

Port-city interface from economic perspective has been weakened during 1990s and 2000s in Korea.

$\begin{array}{lll}\text { Deng } & \text { Structural } & \text { Throughput, quay length, berths, } \\ \text { et al. } & \text { Equation } & \text { VAS, GDP, per capita GDP etc. } \\ \text { (2013) } & \text { Modelling } & \end{array}$

No significant positive effect of port demand and supply on regional economy. Value added activity has positive effect on regional economy.

$\begin{array}{lll}\text { Shan } & \text { Regression } & \text { GDP, GGDP, education, } \\ \text { et al. } & \text { Analysis } & \text { FDI, road, } \\ \text { (2014) } & & \text { throughput etc. }\end{array}$

Significant positive effect on economic growth, consistent with theoretical predictions. Throughput of bigger ports is more significantly associated with local economy than smaller ports.

\begin{tabular}{|c|c|c|c|c|}
\hline $\begin{array}{l}\text { Bottasso } \\
\text { et al. } \\
\text { (2014) }\end{array}$ & $\begin{array}{l}\text { Spatial Panel } \\
\text { Econometric } \\
\text { Framework }\end{array}$ & $\begin{array}{l}\text { GDP, area, population, } \\
\text { throughput, } \\
\text { motorways etc. }\end{array}$ & $\begin{array}{l}\text { Ports tend to increase GDP } \\
\text { of region, where they are } \\
\text { located. Ports also have } \\
\text { large and positive spill-over } \\
\text { on GDP of nearby regions. }\end{array}$ & $\begin{array}{l}13 \mathrm{EU} \\
\text { Countries }\end{array}$ \\
\hline $\begin{array}{l}\text { Chang et } \\
\text { al. (2014) }\end{array}$ & $\begin{array}{l}\text { Input-output } \\
\text { Analysis }\end{array}$ & $\begin{array}{l}95 \text { different } \\
\text { products and services }\end{array}$ & $\begin{array}{l}\text { Port activity is not dependent } \\
\text { on other industry while other } \\
\text { industries are more dependent } \\
\text { on port activity. }\end{array}$ & $\begin{array}{l}\text { South } \\
\text { Africa }\end{array}$ \\
\hline $\begin{array}{l}\text { Park and } \\
\text { Seo } \\
(2016)\end{array}$ & $\begin{array}{l}\text { Augmented } \\
\text { Solow Model }\end{array}$ & $\begin{array}{l}\text { Economic growth rate, cargo } \\
\text { throughput, container throughput, } \\
\text { port investment etc. }\end{array}$ & $\begin{array}{l}\text { Port activities positively affect } \\
\text { regional economic growth, while } \\
\text { port investment indirectly leads to } \\
\text { economic growth. }\end{array}$ & Korea \\
\hline
\end{tabular}




\section{Appendix B}

Table 8 Correlation matrix of latent constructs

\begin{tabular}{lllll}
\hline & QPI & LP & ST & NE \\
\hline QPI & 1.000 & & & \\
LP & 0.674 & 1.000 & & \\
ST & 0.337 & 0.591 & 1.000 & 1.000 \\
NE & 0.578 & 0.731 & 0.359 & \\
\hline
\end{tabular}

QPI quality of port infrastructure, $L P$ logistics performance, ST seaborne trade, NE national economy

\section{Appendix C}

Table 9 List of countries

\begin{tabular}{|c|c|c|c|}
\hline Algeria & Egypt, Arab Rep. & Latvia & Qatar \\
\hline Angola & Finland & Lebanon & Romania \\
\hline Argentina & France & Libya & Russian Federation \\
\hline Australia & Georgia & Lithuania & Saudi Arabia \\
\hline Bahamas & Germany & Malaysia & Senegal \\
\hline Bahrain & Ghana & Malta & Singapore \\
\hline Bangladesh & Greece & Mauritius & Slovenia \\
\hline Belgium & Guatemala & Mexico & South Africa \\
\hline Benin & Honduras & Morocco & Spain \\
\hline Brazil & Hong Kong SAR & Mozambique & Sri Lanka \\
\hline Cambodia & Iceland & Myanmar & Sweden \\
\hline Cameroon & India & Netherlands & Tanzania \\
\hline Canada & Indonesia & New Zealand & Thailand \\
\hline Chile & Iran, Islamic Rep. & Nigeria & Tunisia \\
\hline China & Ireland & Norway & Turkey \\
\hline Colombia & Israel & Oman & Ukraine \\
\hline Congo,Rep. & Italy & Pakistan & United Arab Emirates \\
\hline Costa Rica & Jamaica & Panama & United Kingdom \\
\hline Cote d'Ivoire & Japan & Papua New Guinea & United States \\
\hline Cyprus & Jordan & Peru & Uruguay \\
\hline Denmark & Kenya & Philippines & Venezuela, RB \\
\hline Dominican Republic & Korea, Rep. & Poland & Vietnam \\
\hline Ecuador & Kuwait & Portugal & \\
\hline
\end{tabular}




\section{Additional file}

Additional file 1: Mediation effect in Structural Equation Models. (DOCX 16 kb)

\section{Acknowledgements}

The authors would like to thank Prof. Adolf K. Y. Ng for useful suggestions

Funding

There are no sources of funding to be decleared.

\section{Authors' contributions}

ZHM conceptualised the framework, conducted literature review, data curation, analysis and wrote the first draft. HJS supervised the complete process, enriched the literature review, and reviewed and edited the final draft of the paper. Both authors have read and approved the final version of the manuscript.

\section{Authors' information}

Ziaul Haque Munim is a PhD Research Fellow at the University of Agder, Norway. His main research interests include maritime economics and logistics, supply chain management and international trade. He holds a MSc degree in Supply Chain Management with specializations in transport and logistics, and transport geography modelling from WU Vienna University of Economics and Business. He received the Best Paper Award at the IAME Annual Conference 2016 in Hamburg, Germany.

Hans-Joachim Schramm is a Senior Lecturer at WU - Vienna University of Economics and Business and an external lecturer at Copenhagen Business School (CBS). He holds a diploma degree in economics from Humboldt-University at Berlin and a doctoral degree from Dresden University of Technology. Being a forwarding agent by profession, his main focus of his research is about economics and policy issues in sea, air, rail and road transport markets. He authored several papers and monographs and contributed to peer-review processes at JBL, IJPDLM, IJLM, MPM, LR and JTG. Furthermore, he was visiting lecturer in Belgium, Finland, France, Hungary, Sweden, China and Cuba.

\section{Competing interests}

The authors declare that they have no competing interests.

\section{Publisher's Note}

Springer Nature remains neutral with regard to jurisdictional claims in published maps and institutional affiliations.

\section{Author details}

${ }^{1}$ School of Business and Law, University of Agder, Kristiansand, Norway. ${ }^{2}$ Department of Global Business and Trade, Institute for Transport and Logistics Management, WU Vienna University of Economics and Business, Vienna, Austria. ${ }^{3}$ Department for Operations Management, Copenhagen Business School, Frederiksberg, Denmark.

Received: 27 August 2017 Accepted: 9 January 2018

Published online: 22 January 2018

\section{References}

Anderson JC, Gerbing DW (1988) Structural equation modeling in practice: a review and recommended two-step approach. Psychol Bull 103(3):411-423

Arvis J-F, Mustra MA, Ojala L, Shepherd B, Saslavsky D (2010) Connecting to compete: trade logistics in the global economy, The Logistics Performance Index and Its Indicators. The World Bank, Washington DC

Arvis J-F, Mustra MA, Panzer J, Ojala L, Naula T (2007) Connecting to compete: trade logistics in the global economy, The World Bank, Washington DC

Banister D, Berechman Y (2001) Transport investment and the promotion of economic growth. J Transp Geogr 9(3): 209-218

Bollen KA (1989) Structural equations with latent variables. Wiley, New York

Bollen KA, Long JS (1993) "introduction" in testing structural equation models. Sage, Newbury Park

Bottasso A, Conti M, Ferrari C, Merk O, Tei A (2013) The impact of port throughput on local employment: evidence from a panel of European regions. Transp Policy 27:32-38

Bottasso A, Conti M, Ferrari C, Tei A (2014) Ports and regional development: a spatial analysis on a panel of European regions. Transp Res A Policy Pract 65:44-55

Chang S (1978) In defense of port economic impact studies. Transp J 17:79-85

Chang Y-T, Shin S-H, Lee PT-W (2014) Economic impact of port sectors on south African economy: an input-output analysis. Transp Policy 35:333-340

Chu Z (2012) Logistics and economic growth: a panel data approach. Ann Reg Sci 49(1):87-102

Clark X, Dollar D, Micco A (2004) Port efficiency, maritime transport costs, and bilateral trade. J Dev Econ 75(2):417-450

Coto-Millán P, Agüeros M, Casares-Hontañón P, Pesquera MÁ (2013) Impact of logistics performance on world economic growth (2007-2012). World Review Intermodal Transp Res 4(4):300-310

Cronbach LJ (1951) Coefficient alpha and the internal structure of tests. Psychometrika 16(3):297-334

Deng P, Lu S, Xiao H (2013) Evaluation of the relevance measure between ports and regional economy using structural equation modeling. Transp Policy 27:123-133

Ducruet C, Cuyala S, Hosni AE (2016) The changing influence of city-systems on global shipping networks: an empirical analysis. J Shipping Trade 1(4) 
Dunn SC, Seaker RF, Waller MA (1994) Latent variables in business logistics research: scale development and validation. J Bus Logist 15(2):145-172

Ellis PD (2011) Social ties and international entrepreneurship: opportunities and constraints affecting firm internationalization. J Int Bus Stud 42(1):99-127

Ferrari C, Percoco M, Tedeschi A (2010) Ports and local development: evidence from Italy. Int J Transport Econ 37(1):9-30

Garver MS, Mentzer JT (1999) Logistics research methods: employing structural equation modeling to test for construct validity. J Bus Logist 20(1):33-57

Gordon JR, Lee P-M, Lucas HC (2005) A resource-based view of competitive advantage at the port of Singapore. J Strateg Inf Syst 14(1):69-86

Gripaios P, Gripaios R (1995) The impact of a port on its local economy: the case of Plymouth. Marit Policy Manag 22(1):13-23

Grossmann I (2008) Perspectives for Hamburg as a port city in the context of a changing global environment. Geoforum 39(6): 2062-2072

Hair JF, Black WC, Babin BJ, Anderson RE, Tatham RL (2006) Multivariate data analysis. Pearson Prentice Hall Upper Saddle River Hall PV (2004) "We'd have to sink the ships": impact studies and the 2002 west coast port lockout. Econ Dev Q 18(4):354-367 Hausman WH, Lee HL, Subramanian U (2013) The impact of logistics performance on trade. Prod Oper Manag 22(2): 236-252

Helling A (1997) Transportation and economic development a review. Public Works Manag Policy 2(1):79-93

Helling A, Poister TH (2000) US maritime ports: trends, policy implications, and research needs. Econ Dev Q 14(3):300-317

Hesse M (2006) Global chain, local pain: regional implications of global distribution networks in the German north range. Growth Change 37(4):570-596

Hummels D, Ishii J, Yi K-M (2001) The nature and growth of vertical specialization in world trade. J Int Econ 54(1):75-96

Jung B-M (2011) Economic contribution of ports to the local economies in Korea. Asian J Shipping Logist 27(1):1-30

Kinsey J (1981) The economic impact of the port of Liverpool on the economy of Merseyside-using a multiplier approach. Geoforum 12(4):331-347

Kline RB (2005) Principles and practice of structural equation modeling. The Guilford Press

Korinek J, Sourdin P (2011) To what extent are high-quality logistics services trade facilitating?, OECD Trade Policy Papers, No. 108. OECD publishing, Paris

Koufteros XA (1999) Testing a model of pull production: a paradigm for manufacturing research using structural equation modeling. J Oper Manag 17(4):467-488

Lakshmanan T (2011) The broader economic consequences of transport infrastructure investments. J Transp Geogr 19(1):1-12

Lean HH, Huang W, Hong J (2014) Logistics and economic development: experience from China. Transp Policy 32:96104

Li KX, Jin M, Qi G, Shi W, Ng AK (2017) Logistics as a driving force for development under the belt and road initiative-the Chinese model for developing countries. Transp Rev:1-22. https:/doi.org/10.1080/01441647.2017.1365276

Limao N, Venables AJ (2001) Infrastructure, geographical disadvantage, transport costs, and trade. World Bank Econ Review 15(3): $451-479$

Lu C-S, Lai K-H, Cheng TE (2007) Application of structural equation modeling to evaluate the intention of shippers to use internet services in liner shipping. Eur J Oper Res 180(2):845-867

Lun W. Carlton J, Bichou K (2016) Examining the economic impact of transport complex economies. J Shipping Trade 1(1):1-17

Memedovic O, Ojala L, Rodrigue J-P, Naula T (2008) Fuelling the global value chains: what role for logistics capabilities? International Journal of Technological Learning. Innov Dev 1(3):353-374

Munim, ZH, Saeed N (2016) Seaport competitiveness research: A bibliometric citation meta-analysis. Proceedings of the Annual conference of the International Association of Maritime Economists (IAME) 2016. August 23-26, 2016. Hamburg, Germany

Munim ZH, Schramm HJ (2017) Forecasting container shipping freight rates for the Far East - northern Europe trade lane. Marit Econ Logist 19(1):106-125. https:/doi.org/10.1057/s41278-016-0051-7

Ng AK (2013) The evolution and research trends of port geography. Prof Geogr 65(1):65-86

Notteboom TE, Coeck C, Verbeke A, Winkemans W (1997) Containerization and the competitive potential of upstream urban ports in Europe. Marit Policy Manag 24(3):285-289

Nunnally JC (1978) Psychometric theory, 2nd edn. McGraw-Hill, New York

Panayides PM, Parola F, Lam JSL (2015) The effect of institutional factors on public-private partnership success in ports. Transp Res A Policy Pract 71:110-127

Park JS, Seo Y-J (2016) The impact of seaports on the regional economies in South Korea: panel evidence from the augmented Solow model. Transport Res E-Log 85:107-119

Portugal-Perez A, Wilson JS (2012) Export performance and trade facilitation reform: hard and soft infrastructure. World Dev 40(7): 1295-1307

Rosseel Y (2012) Lavaan: an R package for structural equation modeling. J Stat Softw 48(2):1-36

Sánchez RJ, Hoffmann J, Micco A, Pizzolitto GV, Sgut M, Wilmsmeier G (2003) Port efficiency and international trade: port efficiency as a determinant of maritime transport costs. Marit Econ Logist 5(2):199-218

Shan J, Yu M, Lee C-Y (2014) An empirical investigation of the seaport's economic impact: evidence from major ports in China. Transport Res E-Log 69:41-53

Slack B, Gouvernal E (2015) Container transshipment and logistics in the context of urban economic development. Growth Change 47(3):406-415

Sleeper DM (2012) Port significance: contributions to competitiveness in Latin America and Asia. J Global Business Community 3(1):22-28

Smith A (1776) An inquiry into the nature and causes of the wealth of nations. Edwin Cannan's annotated edition

Song D-W, Panayides PM (2008) Global supply chain and port/terminal: integration and competitiveness. Marit Policy Manag 35(1):73-87

Stopford M (2009) Maritime economics 3e. Routledge, Abingdon

Subramanian U, Anderson WP, Lee K (2005) Measuring the impact of the investment climate on total factor productivity: the cases of China and Brazil. Working paper No. 3792, The Wold Bank, Washington, DC 
Subramanian U, Arnold J (2001) Forging subregional links in transport and trade facilitation. The World Bank, Washington, DC

UNCTAD (2015) Review of maritime transport. United Nations conference on trade and development. United Nations Publication, Geneva

van den Heuvel FP, Rivera L, van Donselaar KH, de Jong A, Sheffi Y, de Langen PW, Fransoo JC (2014) Relationship between freight accessibility and logistics employment in US counties. Transp Res A Policy Pract 59:91-105

Wang T-F, Cullinane K (2006) The efficiency of European container terminals and implications for supply chain management. Marit Econ Logist 8(1):82-99

Wilmsmeier G, Hoffmann J (2008) Liner shipping connectivity and port infrastructure as determinants of freight rates in the Caribbean. Marit Econ Logist 10(1-2):130-151

Yeo GT, Roe M, Dinwoodie J (2008) Evaluating the competitiveness of container ports in Korea and China. Transp Res A Policy Pract. 42(6):910-921

Yochum GR, Agarwal VB (1987) Economic impact of a port on a regional economy: note. Growth Change 18(3):74-87

Submit your manuscript to a SpringerOpen ${ }^{\circ}$ journal and benefit from:

- Convenient online submission

- Rigorous peer review

- Open access: articles freely available online

- High visibility within the field

- Retaining the copyright to your article

Submit your next manuscript at $>$ springeropen.com 